\title{
PREDISPOSITION OF DOG BREEDS TO RUPTURE OF THE CRANIAL CRUCIATE LIGAMENT
}

\author{
A. NEČAS ${ }^{1}$, J. ZATLOUKAL ${ }^{2}$, H. KECOVÁ ${ }^{1}$, M. DVOŘÁK ${ }^{1}$ \\ ${ }^{1}$ Department of Surgery and Orthopedics, Small Animal Clinic, University of Veterinary and Pharmaceutical \\ Sciences, Brno, Czech Republic \\ ${ }^{2}$ Department of Diagnostic Imaging, Small Animal Clinic, University of Veterinary and Pharmaceutical \\ Sciences, Brno, Czech Republic
}

Received September 6, 2000

Accepted November 22, 2000

Abstract

Nečas A., J. Zatloukal, H. Kecová, M. Dvořák: Predisposition of Dog Breeds to Rupture of Cranial Cruciate Ligament. Acta Vet. Brno 2000, 69: 305-310.

Obtaining more data on breed predisposition of dogs to the cranial cruciate ligament (CCL) rupture and data on accompanying abnormalities of joints of pelvic limbs affected by the CCL rupture may help in answering some questions concerning the etiology and pathogenesis of the disorder.

In 183 patients affected by the CCL rupture out of the total of 11579 dogs, evaluated and/or treated in the Clinic of Surgery and Orthopedics at the Veterinary and Pharmaceutical University Brno from January 1997 till April 2000, the breed, weight, sex and concurrent joint abnormalities of pelvic limbs (hip dysplasia, patellar luxation and osteochondrosis of the stifle joint) were recorded.

A total of 213 stifle joints (16.39\% of cases were bilateral CCL ruptures) were affected. Increased breed predisposition $\left(\chi^{2}\right.$-test; $\left.p<0.01\right)$ was found in American Staffordshire Terrier, Rottweiler, Brazilian Fila, Labrador Retriever, American Cocker Spaniel, Chow Chow, German Shorthaired Pointer, Saint Bernard and Bullmastiff and also on the $5 \%$ level of significance in Boxer.

Contrary to published data, the high incidence of CCL rupture was found in Brazilian Fila (13.43\% of prevalence). The risk of the CCL rupture in German Shepherd Dog was significantly lower $\left(\chi^{2}\right.$-test; $\left.p<0.01\right)$ than in other breeds studied. At the same time in 27 patients with the CCL rupture we diagnosed canine hip dysplasia, in 9 dogs medial patellar luxation and in 5 cases osteochondrosis of the stifle joint. The data found are briefly discussed in relation to the possible CCL rupture etiology.

Stifle joint, cranial cruciate ligament injury, prevalence, etiopathogenesis

Cranial cruciate ligament (CCL) rupture belongs to the most frequent acquired diseases of the stifle joint not only in dogs and cats (Ryer 1981) but also in man (Griffin et al. 2000). Many questions concerning the etiopathogenesis of the CCL rupture remains unanswered. The integrity of the cranial cruciate ligament may be lost due to direct trauma of the stifle which may also result in damage of other structures of the stifle such as the caudal cruciate ligament, medial and lateral collateral ligaments, meniscus, joint capsule and eventually bone structures of the joint (femur, tibia and patella) (Bruce 1998). The number of cases of in such a way originated CCL ruptures is relatively small. With regard to the absence of direct trauma of the stifle joint in most cases of CCL rupture, various predisposing factors taking part in decreasing the firmness of the ligament, resulting in its inability to stand up to normal loading and subsequent rupture have been considered. Decreased CCL resistance to forces of pull has been proved in animals with aging. Results of concurrent histological examination have proved degenerative changes of the ligament that were more severe with advancing age of dogs and occurred earlier in dogs of large breeds (body weight $>15 \mathrm{~kg}$ ) (Vasseur et al. 1985). There may also be other predisposing factors such as

Address for correspondence:

Doc. MVDr. Alois Nečas, Ph.Dr.

Department of Surgery and Orthopedics, Small Animal Clinic

University of Veterinary and Pharmaceutical Sciences
Palackého 1-3, 612 42 Brno, Czech Republic
Phone: +420602742484

Fax: +420541562344

http://www.vfu.cz/acta-vet/actavet.htm 
immune-mediated arthropathies (Niebauer and Menzel 1982; Niebauer et al. 1987), abnormalities in the stifle joint constitution (Arnoczky 1993) and growth deformities with abnormal stance of pelvic limbs (Read and Robins 1982). Predisposition to the CCL rupture in dogs was proved in many breeds (Duval et al. 1999; Whitehair et al. 1993). Whitehair et al. (1993) mentions increased occurrence of the CCL rupture in females. Surgically sterilized dogs (male and female) suffered from the CCL rupture more often. The CCL injury occurred most frequently from 7 to 10 years of age (Whitehair et al. 1993). There was a higher incidence of the CCL rupture found in dogs of large breeds $(>22 \mathrm{~kg}$ ) than in smaller breeds $(\leq 22 \mathrm{~kg})$ and the clinical symptoms appeared at a younger age (Whitehair et al. 1993). Duval et al. (1999) found, that in the group of young dogs up to two years of age having the CCL rupture mostly large breeds $(>22 \mathrm{~kg}$ ) are represented.

This study is aimed at determining the dog breed predisposition to the CCL rupture, finding out concurrent orthopedic abnormalities in the limb affected by the CCL rupture and relating the data to the possible CCL rupture aetiology.

\section{Materials and Methods}

From the dogs evaluated and/or treated in the Clinic of Surgery and Orthopedics at the Veterinary and Pharmaceutical University Brno from the beginning of January 1997 till the end of April $2000(\mathrm{n}=11579)$, dog patients, in which the CCL rupture was clearly and fully diagnosed, were included in this study. Diagnosis of the CCL rupture was based on orthopedic examination including specific tests such as the cranial draver sign in the stifle joint and the tibial compression test, and radiographic findings (joint effusion, arthrotic changes, cranial displacement of the tibia relative to the femur) and/or stifle joint arthrotomy. Data on breed, body weight, sex and concurrent orthopedic abnormalities of hind limb (hip dysplasia, patellar luxation and osteochondrosis of the stifle joint) of each patient were recorded. In each clinical case of the CCL rupture such data as the age of the patient at the time of the rupture (there could have been differences in bilaterally affected animals) and the side of pathological changes localisation in the stifle were determined. We computed mean values and standard deviation values for the body weight and age of patients. The breed predisposition (evaluated using the $\chi^{2}$-test) and prevalence of the CCL rupture (expressed as per cent) included only such breeds that were represented by two or more individuals affected by the CCL rupture. Breed prevalence values were computed as the proportion of affected patients of a given breed to the total number of individuals of that breed treated.

\section{Results}

The CCL rupture was diagnosed in 183 patients $(1.58 \%)$ of 48 dog breeds including mongrels out of the total of 11579 dogs during a period longer than 3 years. We found increased breed predisposition $\left(\chi^{2}\right.$-test; $\left.p<0.01\right)$ in the following breeds represented by at least two cases of CCL rupture: American Staffordshire Terrier, Rottweiler, Brazilian Fila, Labrador Retriever, American Cocker Spaniel, Chow Chow, German Shorthaired Pointer, Saint Bernard and Bullmastiff. We also proved increased breed predisposition in Boxers on the level of significancy $p<0.05$ ( $\chi^{2}$-test). We did not find increased risk for the CCL rupture in mongrels and the following breeds: Poodle, Doberman Pinscher, Maltese, Rhodesian Ridgeback, Spitz, Beagle, Cocker Spaniel, Golden Retriever, Giant Schnauzer, West Highland White Terrier and Yorkshire Terrier. The risk of the CCL rupture was significantly lower $\left(\chi^{2}\right.$-test; $\left.p<0.01\right)$ in German Shepherd Dogs. Table 1 shows the prevalence of the CCL rupture in breeds represented by at least two cases of rupture.

In all, there were 213 stifle joints affected in these 183 patients with diagnosed CCL rupture. A total of 30 dogs (16.39\%) were bilaterally affected and the remaining 153 dogs $(83,61 \%)$ had only unilateral changes. The joint of the right limb was affected in 135 cases $(63.38 \%)$ and the (left) other one in 78 cases (36.62\%). There were 98 males (53.55\%) and 85 females $(46.45 \%)$. The age of patients at the time of the CCL rupture varied from 1 to 18 years with the mean age of $5.71 \pm 3.89$ years. The body weight of patients varied from 2 to $80 \mathrm{~kg}$ with the mean value of $24.20 \pm 15.93 \mathrm{~kg}$.

Routine clinical and radiographic evaluation resulted in finding hip dysplasia, apart from 
Table 1

Risk of CCL rupture for breeds of dogs represented by $\geq 2$ cases

\begin{tabular}{|c|c|c|c|}
\hline Breed & $\begin{array}{c}\text { Number of affected } \\
\text { dogs }\end{array}$ & $\begin{array}{c}\text { Number of dogs in } \\
\text { population }\end{array}$ & Prevalence $(\%)$ \\
\hline \multicolumn{4}{|l|}{ High at risk } \\
\hline American Staffordshire Terrier & 16 & 246 & 6.50 \\
\hline Rottweiler & 12 & 213 & 5.63 \\
\hline Boxer & 9 & 273 & 3.30 \\
\hline Brazilian Fila & 9 & 67 & 13.43 \\
\hline Labrador Retriever & 7 & 149 & 4.70 \\
\hline American Cocker Spaniel & 6 & 130 & 4.62 \\
\hline Chow Chow & 4 & 25 & 16.00 \\
\hline German Shorthaired Pointer & 4 & 71 & 5.63 \\
\hline Saint Bernard & 3 & 20 & 15.00 \\
\hline Bullmastiff & 2 & 22 & 9.10 \\
\hline \multicolumn{4}{|l|}{ Not at risk } \\
\hline Mongrel & 29 & 1569 & 1.85 \\
\hline Poodle & 22 & 988 & 2.28 \\
\hline Doberman Pinscher & 7 & 414 & 1.70 \\
\hline Maltese & 3 & 103 & 2.91 \\
\hline Rhodesian Ridgeback & 3 & 73 & 4.11 \\
\hline Spitz & 3 & 161 & 1.86 \\
\hline Beagle & 2 & 67 & 2.99 \\
\hline Cocker Spaniel & 2 & 553 & 0.36 \\
\hline Golden Retriever & 2 & 113 & 1.77 \\
\hline Giant Schnauzer & 2 & 105 & 1.91 \\
\hline West Highland White Terrier & 2 & 48 & 4.18 \\
\hline Yorkshire Terrier & 2 & 269 & 0.74 \\
\hline \multicolumn{4}{|l|}{ Low at risk } \\
\hline German Shepherd Dog & 7 & 1321 & 0.52 \\
\hline
\end{tabular}

the CCL rupture, in 27 patients (exclusively dogs of large and giant breeds, weighing $>22 \mathrm{~kg}$ ). In 9 cases (exclusively dogs of small and medium size breeds, weighing $\leq 22 \mathrm{~kg}$ ) we found medial patellar luxation in the joint affected by the CCL rupture, and in 5 cases (exclusively dogs of large and giant breeds, weighing $>22 \mathrm{~kg}$ ) osteochondrosis was also diagnosed in the affected stifle. Lesions of osteochondrosis were localised in all cases on the lateral femoral condyle.

\section{Discussion}

The cranial cruciate ligament rupture belongs to relatively frequent disorders in dogs. In our collection patients with this disorder amounted to $1.58 \%$ of all the dogs treated, which is a similar incidence as that mentioned by other authors (John s on et al. 1994; Whitehair 
et al. 1993). As far as diseases of the stifle joint are concerned, the CCL rupture takes part in more than one half of cases (Johns on et al. 1994).

According to Whitehair et al. (1993) the CCL rupture occurs more frequently in large dog breeds ( $>22 \mathrm{~kg}$ ). We also found (within our study) that in the group of 10 breeds with significantly higher CCL rupture incidence 9 breeds were weighing more than $22 \mathrm{~kg}$ (American Staffordshire Terrier, Rottweiler, Boxer, Brazilian Fila, Labrador Retriever, Chow Chow, German Shorthaired Pointer, Saint Bernard and Bullmastiff) and only one breed less than $22 \mathrm{~kg}$ (American Cocker Spaniel). Though dogs of large breeds are most frequently affected, body weight of patients cannot be considered as the only predisposing factor regarding the fact that the German Shepherd belongs to breeds with lower incidence of the CCL rupture (White hair et al. 1993). We also found increased CCL rupture incidence in Brazilian Fila, which was not mentioned as a predisposed breed by Whitehair et al. (1993). Contrary to this, it was one of the most frequently affected breeds ( $13.43 \%$ of prevalence) in our study.

In the above-mentioned breeds we can recognise some abnormalities which may contribute to the CCL rupture such as a hyperextended stance of pelvic limbs (Arnoczky and Marshall 1977) frequently occurring in breeds such as Chow Chow, Rottweiler, American Staffordshire Terrier, Boxer, Brazilian Fila, Saint Bernard and Bullmastiff. One of the causes of hyperextended stance of pelvic limbs can be hip dysplasia, which was diagnosed in our collection of patients in 27 cases of the CCL rupture (exclusively dogs of large and giant breeds, weighing $>22 \mathrm{~kg}$ ). Other predisposing factors might be obesity to which there is a higher disposition in Labrador Retrievers and Cocker Spaniels (Edney and Smith 1986) and quick maximum load (Arnoczky 1993; Cabaud 1983) mainly in working and prone to aggression breeds such as Chow Chow, Rottweiler, American Staffordshire Terrier, Brazilian Fila and German Shorthaired Pointer. Even this explanation of predisposing factors for the CCL rupture is not unambiguous because there are breeds that fall into the abovementioned criteria and, in spite of this, higher incidence of this disorder is not noticed.

In some dogs the CCL rupture may be associated with medial patellar luxation (Arnoczky 1993; Moore and Read 1996). This disorder was found in 9 cases of the CCL rupture in our collection of patients exclusively in dogs of small and medium size breeds (body weight $\leq 22 \mathrm{~kg}$ ).

A number of papers proved a higher incidence of the CCL rupture in females than in males (Barnes 1977; Denny and Minter 1973; Whitehair et al. 1993). In our sample of patients males and females were rather equally represented (53.55\% of males and $46.45 \%$ of females).

Mean age of dogs at the time of the CCL rupture in our clinical sample of patients was $5.71 \pm 3.89$ years. The highest incidence of CCL rupture was recorded between 2 and 4 years of age. This range of age is somewhat lower than commonly mentioned data on the highest incidence of this disease in dogs of 7 to 10 years of age (Whitehair et al. 1993). It may be, apart from other causes, due to the fact that in our group there was a higher number of large dog breeds, in which there is an earlier occurrence of the CCL rupture (Duval et al. 1999).

Bilateral stifle joint affection in our collection of 183 dogs with the CCL rupture was found in 30 individuals (16.39\% of cases) during the study period. As mentioned in the literature the incidence of bilateral CCL rupture varies from $8 \%$ (B ennett et al. 1988) to 31-37\% (Duval et al. 1999; Pond and Campbell 1972). Regarding the relatively short period of pursuing our patients, the real number of cases of bilateral CCL rupture would probably be higher in our group of patients.

Disruption of integrity of intraarticular ligaments and their subsequent rupture may be caused by immune-mediated arthropathies. The arthropaties mentioned affect more joints and may cause bilateral CCL ruptures (Goring and Beale 1993, Moore and Read 1996) which are most often found in lymphocytic-plasmacytic synovitis (Hopper 1993). The fact 
that immune-mediated mechanisms play an important role in pathophysiology of the CCL rupture is supported by a number of studies (Galloway and Lester 1995; Lawrence et al. 1998; Nieb buer and Menzel 1982; Niebauer et al. 1987). It is supposed that there may be also other factors taking part in etiopathogenesis of CCL rupture such as degenerative changes of the CCL (V as seur et al. 1985). These changes in the cranial cruciate ligament are then the precondition to the rupture under fewer loads compared to the healthy ligament. Poor blood supply to the central part of the ligament may be one cause of degenerative changes of the CCL in dogs (Tirg ari 1978). More study is required to explain all unanswered questions concerning etiopathogenesis of this common orthopaedic condition.

\section{Plemenná predispozice psů k ruptuře předního zkříženého vazu}

Rozšíření údajů o plemenné predispozici psů k ruptuře předního zkřǐženého vazu a doprovodných abnormalitách kloubů pánevních končetin postižených rupturou LCC může přispět k objasnění některých otázek etiopatogeneze uvedeného onemocnění.

U 183 pacientů s rupturou kraniálního zkřiženého vazu ze souboru 11579 psů vyšetřených a/nebo ošetřených na Klinice chirurgie a ortopedie Veterinární a farmaceutické univerzity v Brně v období od ledna 1997 do dubna 2000 bylo zaznamenáno plemeno, hmotnost, pohlaví a souběžné abnormality kloubů pánevních končetin (dysplazie kyčelního kloubu, luxace pately a osteochondróza kolenního kloubu).

Celkem bylo postiženo 213 kolenních kloubů (16,39\% případů byly bilaterální ruptury LCC). Zjišš̌na byla zvýšená plemenná predispozice $\left(\chi^{2}\right.$-test; $\left.p<0,01\right)$ u amerického stafordšírského teriéra, rotvajlera, brazilské fily, labradorského retrívra, amerického kokršpaněla, čau-čau, německého krátkosrstého ohaře, bernardýna, bulmastifa a na $5 \%$ hladině významnosti $\left(\chi^{2}\right.$-test) také u boxera.

Na rozdíl od dostupných literárních údajů byla prokázána vysoká incidence ruptury LCC také u brazilské fily (prevalence 13,43 \%). Riziko vzniku ruptury LCC u německých ovčáků bylo signifikantně nižší $\left(\chi^{2}\right.$-test; $\left.p<0,01\right)$ než u ostatních sledovaných plemen. U 27 pacientů s rupturou LCC byla současně diagnostikována dysplazie kyčelních kloubů, u 9 psů mediální luxace pately a v 5 případech osteochondróza kolenního kloubu. Zjištěné údaje jsou diskutovány v souvislosti s možnou etiologií ruptury LCC.

\section{Acknowledgements}

This work was supported by the Ministry of Education, Youth and Sports of the Czech Republic (Research Project No. 161700002)

\section{References}

ARNOCZKY, S. P, MARSHALL, J. L. 1977: The cruciate ligament of the canine stifle: an anatomical and functional analysis. Am. J. Vet. Res. 38: 1807-1814

ARNOCZKY, S.P. 1993: Pathomechanics of cruciate ligament and meniscal injuries. In: BOJRAB, M. J.: Disease mechanisms in small animal surgery. $2^{\text {nd }}$ ed. Lea \& Febiger, Philadelphia, pp. 764-776

BARNES, A. J. 1977: Rupture of the anterior cruciate ligament of the dog: A survey from practices in the Kent region BSAVA. J. Small Anim. Pract. 18: 55-57

BENNETT, D., TENNANT, B., LEWIS, D. G., BAUGHAN, J., MAY, C., CARTER, S. 1988: A reappraisal of anterior cruciate ligament disease in the dog. J. Small Anim. Pract. 29: 275-297

BRUCE, W. J. 1998: Multiple ligamentous injuries of the canine stifle joint: a study of 12 cases. J. Small Anim. Pract. 39: 333-340

CABAUD, H. E. 1983: Biomechanics of the anterior cruciate ligament. Clin. Orthop. 172: 26-31

DENNY, H. R., MINTER, H. M. 1973: The long term results of surgery of canine stifle disorders. J. Small Anim. Pract. 14: 695-713

DUVAL, J. M., BUDSBERG, S. C., FLO, G. L., SAMMARCO, J. L. 1999: Breed, sex, and body weight as risk factors for rupture of cranial cruciate ligament in young dogs. J. Am. Vet. Med. Assoc. 215: 811-814

EDNEY, A. T. B., SMITH, P. M. 1986: Study of obesity in dogs visiting veterinary practices in the United Kingdom. Vet. Rec. 118: 391-396 
GALLOWAY, R.H., LESTER, S. J. 1995: Histopathological evaluation of canine stifle joint synovial membrane collected at the time of repair of cranial cruciate ligament rupture. J. Am. Anim. Hosp. Assoc. 31: 289-294

GORING, R. L., BEALE, B. S. 1993: Immune-mediated arthropathies. In: BOJRAB, M.J.: Disease mechanisms in small animal surgery. $2^{\text {nd }}$ ed. Lea $\&$ Febiger, Philadelphia, pp. $742-757$

GRIFFIN, L. Y., AGEL, J., ALBOHM, M. J., ARENDT, E. A., DICK, R. W., GARRETT, W. E., GARRICK, J. G., HEWETT, T. E., HUSTON, L., IRELAND, M. L., JOHNSON, R. J., KIBLER, W. B., LEPHART, S., LEWIS, J. L., LINDENFELD, T. N., MANDELBAUM, B. R., MARCHAK, P., TEITZ, C. C., WOJTYS, E. 2000: Noncontact anterior cruciate ligament injuries: risk factors and prevention strategies. J. Am. Acad. Orthop. Surg. 8:141-150

HOPPER, P. E. 1993: Immune-mediated joint diseases. In: SLATTER, D.: Textbook of Small Animal Surgery, 2nd ed., W. B. Saunders, Philadelphia, pp. 1928-1937

JOHNSON, J. A., AUSTIN, C., BREUR, G. . 1994: Incidence of canine appendicular musculoskeletal disorders in 16 veterinary teaching hospitals from 1980 through 1989. Vet. Comp. Orthop. Trauma 7: 56-69

LAWRENCE, D., BAO, S., CANFIELD, P. J., ALlANSON, M., HUSBAND, A. J. 1998: Elevation of immunoglobulin deposition in the synovial membrane of dogs with cranial cruciate ligament rupture. Vet. Immunol. Immunopathol. 65: 89-96

MOORE, K. W., READ, R. A. 1996: Rupture of the cranial cruciate ligament in dogs- part 1. Compend. Contin. Educ. Pract. Vet. 18: 223-233

NIEBAUER, G. W., MENZEL, E. J. 1982: Imunological changes in canine cruciate ligament rupture. Res. Vet. Sci. 32: 235-241

NIEBAUER, G. W., WOLF, B., BASHEY, R. I., NEWTON, C. D. 1987: Antibodies to canine collagen types I and II in dogs with spontaneous cruciate ligament rupture and osteoarthritis. Arthritis Rheum. 30: 319-327

POND, M. J., CAMPBELL, J. R. 1972: The canine stifle joint: rupture of the anterior ligament. J. Small Anim. Pract. 13: $1-10$

READ, R.A., ROBINS, G. M. 1982: Deformity of proximal tibia in dogs. Vet. Rec. 111: 295-298

RYER, K. A. 1981: Rupture of the anterior cruciate ligament rupture in a cat. Feline Pract. 11: 15-16

TIRGARI, M. 1978: The surgical significance of the blood supply of the canine stifle joint. J. Small Anim. Pract. 19: 451-462

VASSEUR, P. B., POOL, R. R., ARNOCZKY, S. P., LAU, R. E. 1985: Correlative biomechanical and histologic study of the cranial cruciate ligament in dogs. Am. J. Vet. Res. 46: 1842-1854

WHITEHAIR, J. G., VASSEUR, P. B., WILLITS, N. H. 1993: Epidemiology of cranial cruciate ligament rupture in dogs. J. Am. Vet. Med. Assoc. 203: 1016-1019 